\title{
SISTEM PENDUKUNG KEPUTUSAN TINGKAT KEPUASAN PASIEN TERHADAP MUTU PELAYANAN RUMAH SAKIT BERDASARKAN METODE SERVQUAL
}

\author{
Beny Irawan ${ }^{1}$ Erwin Daniel Sitanggang ${ }^{2}$, Sayed Achmady ${ }^{3}$ \\ ${ }^{1}$ Institut Kesehatan Medistra Lubuk Pakam \\ Jl. Sudirman No. 38, Lubuk Pakam, Kec. Lubuk Pakam Pekan, Kab. Deli Serdang, Sumatera Utara \\ ${ }^{2}$ AMIK Medan Business Polytechnic \\ Jl. Jamin Ginting No. 285-287, Padang Bulan, Medan Baru, Kota Medan, Sumatera Utara \\ ${ }^{3}$ Universitas Jabal Ghafur \\ Jl. Gle Gapui, Peutoe, Sigli, Kab. Pidie, Aceh \\ 'benyirawan77@gmail.com, ${ }^{2}$ rwins.sitanggang@gmail.com, ${ }^{3}$ sayedachmady@gmail.com
}

\begin{abstract}
Abstrak - Pengukuran tingkat kepuasan pasien akan pelayan yang diberikan oleh institusi rumah sakit akan menjadi tolak ukur dalam meningkatkan mutu pelayanan. Teknologi informasi dan komunikasi dapat dimanfaatkan untuk mempercepat proses pengukuran mulai dari pengumpulan data hingga mendapatkan hasil analisis yang dapat digunakan sebagai data pendukung dalam pengambilan keputusan. Sistem pendukung keputusan yang ter komputerisasi dirancang memanfaatkan diagram-diagram yang ada pada Unified Modelling Language (UML) sebelum dikembangkan menjadi sebuah perangkat lunak. Hasil dari penelitian ini berupa perangkat lunak yang dikembangkan dari perancangan yang terstruktur yang dapat digunakan sebagai alat pengumpulan data kemudian mengolahnya hingga menganalisis data menjadi informasi yang akurat untuk digunakan dalam pengambilan keputusan.
\end{abstract}

Kata Kunci- Sistem Pendukung Keputusan, Servqual, Tingkat Kepuasan Pasien, Mutu Pelayanan.

Abstract-Measuring the level of patient satisfaction with the service provided by the hospital institution will be a benchmark in improving the quality of service. Information and communication technology can be used to speed up the measurement process starting from data collection to obtaining analysis results that can be used as supporting data in decision making. A computerized decision support system is designed to make use of the existing diagrams in the Unified Modeling Language (UML) before being developed into a software. The results of this research are in the form of software developed from a structured design that can be used as a data collection tool and then process it to analyze the data into accurate information for use in decision making.

Keywords — Decision Support System, Servqual, Patient Satisfaction Level, Service Quality.

\section{PENDAHULUAN}

Pemanfaatan teknologi informasi dan komunikasi telah mempermudah manusia dalam menyelesaikan pekerjaan sehari-hari di berbagai bidang kehidupan. Salah pemanfaatan dari teknologi informasi yang telekomunikasi ini yaitu pengolahan data untuk menghasilkan informasi yang dapat digunakan sebagai data pendukung dalam pengambilan keputusan. Informasi yang dihasilkan haruslah terjamin kebenarannya, mencerminkan keadaan yang sebenarnya, sesuai dengan yang dibutuhkan, diberikan secara utuh dan mempunyai manfaat yang lebih besar dibandingkan dengan biaya untuk mendapatkannya.

Dalam menjalankan operasionalnya, rumah sakit rumah sakit melakukan pengukuran tingkat kinerja dari pelayanan jasa kesehatan yang mereka berikan kepada pasien. Informasi dari hasil pengukuran akan menjadi tolak ukur apakah operasional telah berjalan sesuai dengan yang diinginkan dan juga menjadi acuan dalam meningkatkan mutu kualitas pelayanan di kemudian hari.

Namun pengolahan data pada saat melakukan pengukuran tingkat kinerja masih dilakukan secara manual dengan memanfaatkan aplikasi pengolah angka (spreadsheet). Terkadang untuk mendapatkan informasi yang baik dan akurat membutuhkan waktu yang lama dan tingkat ketelitian yang tinggi. Serta pencarian data dari pengukuran yang dilakukan pada periode sebelumnya susah untuk ditemukan.

Untuk mempercepat proses pengukuran tingkat kinerja dan mengurangi tingkat kesalahan dalam pengolah data, penulis mengembangkan sistem pendukung keputusan. Sistem pendukung keputusan dirancang menggunakan Unified Modelling Language (UML) dengan metode analisis pengukuran tingkat kinerja pelayanan jasa yang digunakan adalah Service Quality (servqual). Pengembangan sistem pendukung keputusan ini diharapkan dapat menghemat waktu dalam pelaksanaan pengukuran tingkat kinerja, 
mengurangi biaya dan menghasilkan analisis yang akurat.

\section{KAJIAN TEORI}

Kajian teori dalam penelitian terdiri dari empat Page|11 bagian yaitu: Sistem Pendukung Keputusan, Service Quality (servqual), Unified Modelling Language (UML) dan User Interface.

\section{A. Sistem Pendukung Keputusan}

Sistem pendukung keputusan merupakan perangkat lunak (software) komputer yang dapat menghasilkan informasi pendukung dalam pengambilan keputusan untuk menyelesaikan masalah yang semi terstruktur dengan mengolah data, informasi dan rancangan model. Dalam hal ini, sistem pendukung keputusan bukanlah alat dalam pengambilan keputusan, tetapi merupakan alat pendukung. Karakteristik sistem pendukung keputusan menurut Turban dalam Rohayani (2013) haruslah mudah untuk digunakan, menggunakan model-model dalam menganalisis data serta mendukung di seluruh tahap proses pengambilan keputusan yaitu intelegence, design, choise dan implementasi.

Menurut Turban dalam Rohayani (2013), penerapan sistem pendukung keputusan mempunyai tujuan membantu manajerial dalam pengambilan keputusan atas masalah semi terstruktur, meningkat efektivitas keputusan yang diambil oleh manajer dan dapat digunakan oleh para anggota yang berasal dari berbagai lokasi yang berbeda (penghematan biaya perjalan).

\section{B. Service Quality (ServQual)}

Service Quality (ServQual) merupakan salah satu metode pengukuran kualitas pelayanan yang dibangun berdasarkan perbandingan persepsi pelanggan atas kenyataan layanan yang mereka terima dengan layanan yang sesungguhnya mereka harapkan (Irawan et al, 2020). Apabila kenyataan layanan melebihi dari layanan yang diharapkan maka layanan dikatakan bermutu, bila kenyataan layanan kurang dari layanan yang diharapakan maka layanan dikatakan tidak bermutu dan bila kenyataan layanan sama dengan layanan yang diharapkan maka dikatakan layanan tersebut memuaskan.

Pelayanan yang diberikan oleh pemberi layanan pada dasarnya haruslah sama dengan yang diharapkan oleh pelanggan. Harapan pelanggan ini bersumber dari informasi dari mulut ke mulut, kebutuhan pribadi pelanggan, pengalaman masa lalu yang dialami pelanggan dan komunikasi eksternal (iklan dan berbagai bentuk promosi pemberi layanan lainnya).

Menurut Parasuraman dalam Sitanggang (2018), terdapat 5 dimensi pengukuran kualitas mutu layanan dari servqual, sebagai berikut:

1. Tangibles (Bukti Fisik), sarana dan prasarana fisik yang dimiliki oleh penyedia layanan dan keadaan lingkungan sekitarnya.
2. Reliability (Kehandalan), kemampuan memberikan layanan sesuai dengan yang dijanjikan dan berkinerja tepat waktu, tanpa kesalahan, simpatik dan dengan akurasi tinggi.

3. Responsiveness (Daya Tanggap), kemauan untuk membantu dan serta memberikan pelayanan yang cepat dan tepat kepada penerima layanan, dengan penyeampaian informasi yang jelas.

4. Assurance (Jaminan), pengetahuan, sopan santun dan kemampuan pemberi layanan dalam menumbuhkan kepercayaan dari penerima layanan.

5. Empathy (Empati), kemampuan dalam memahami keinginan penerima layanan secara pribadi dan tulus.

Untuk mendapatkan nilai kesenjangan (gap) untuk setiap dimensi diperoleh dengan rumus:

\section{Servqual Gap = Nilai Persepsi - Nilai Harapan}

Adapun langkah-langkah pengukuran mutu pelayanan dengan metode servqual adalah sebagai berikut (Sitanggang et al, 2018) :

1. Menghitung seluruh nilai persepsi pada setiap variabel $\mathrm{X}_{\mathrm{i}}$ dan nilai harapan pada setiap nilai $\mathrm{Y}_{\mathrm{i}}$.

2. Menjumlahkan seluruh nilai harapan $\left(\mathrm{Y}_{\mathrm{i}}\right)$ dan nilai persepsi $\left(\mathrm{X}_{\mathrm{i}}\right)$ dari seluruh variabel dan kemudian dihitung nilai rata-ratanya $\overline{(\mathrm{Y})}$ dan $\overline{(\mathrm{X})}$.

$$
\overline{\mathrm{X}}=\frac{\sum X i}{\mathrm{n}} \quad \overline{\mathrm{Y}}=\frac{\sum Y i}{\mathrm{n}}
$$

Dimana:

$\overline{\mathrm{X}}=$ Nilai rata-rata tingkat persepsi

$\overline{\mathrm{Y}}=$ Nilai rata-rata tingkat harapan

$\mathrm{n}=$ Jumlah responden

3. Menghitung nilai kesenjangan antara nilai rata-rata dari persepsi dengan nilai rata-rata harapan.

$$
\mathrm{NS}_{\mathrm{i}}=\overline{(\mathrm{Xi})}-\overline{(\mathrm{Yi})}
$$

Dimana :

$\mathrm{NS}_{\mathrm{i}}=$ Nilai rata-rata kesenjangan ke-i

4. Menghitung nilai rata-rata kesenjangan setiap variabel.

$$
\overline{\mathrm{NSi}}=\frac{\sum N S i}{A i}
$$

Dimana :

$\overline{\mathrm{NSi}}=$ Nilai rata-rata kesenjangan per variabel ke-i $\mathrm{Ai}$ = Banyaknya atribut tiap variabel ke-i

5. Menjumlahkan nilai kesenjangan tiap dimensi kemudian dilakukan diambil selisih kesenjangan antara persepsi dengan harapan dan mengambilkan 
kesimpulan akan mutu pelayanan serta perbaikan atribut pelayanan dengan ketentuan:

- Bila persepsi > harapan disebut bermutu (Pertahankan).

- Bila persepsi < harapan disebut tidak bermutu (Perbaikan).

- Bila persepsi = harapan disebut memuaskan (Tingkatkan).

\section{Unified Modelling Language (UML)}

Unified Modelling Language (UML) merupakan salah satu standar bahasa pemodelan berorientasi objek yang banyak digunakan di dunia industri untuk visualisasi, perancangan dan pendokumentasian perangkat lunak (Putra el al, 2019). Pada UML juga memberikan standar penulisan sebuah blue print sistem yang lengkap dan detail yang siap untuk digunakan dalam mengembangkan sistem dan untuk tukar menukar model yang dapat digunakan manusia maupun mesin.

Diagram UML yang digunakan dalam merancang penelitian ini yaitu (Putra et al, 2019) :

1. Use Case Diagram, diagram yang menggambarkan hubungan antara sistem dengan aktor maupun mendeskripsikan hubungan antara si pengguna sistem dengan sistem yang akan dibuat.

2. Class Diagram, diagram yang menggambarkan struktur sistem berupa pendefinisian kelas-kelas maupun paket-paket yang akan digunakan untuk membangun sistem.

3. Activity Diagram, diagram yang menggambarkan rangkaian aliran dari proses-proses maupun aktifitas-aktifitas yang dibentuk dalam sebuah operasi yang terjadi pada sistem.

4. Sequence Diagram, diagram yang menggambarkan hubungan maupun tingkah laku objek yang ada pada use case diagram berdasarkan masa hidup dari objek dan rangkaian pesan yang diterima maupun dikirimkan antar objek.

5. Deployment Diagram, diagram yang menggambarkan arsitektur dari perangkat keras dan perangkat lunak sistem, menunjukkan hubungan antara perangkat (nodes) yang digunakan satu sama lain serta jenis hubungannya.

\section{ANALISIS DAN PERANCANGAN}

Pada bab ini akan dijelaskan cara pengumpulan data, metode servqual yang digunakan dalam menganalisis data untuk mendapatkan keputusan serta rancangan untuk pengembangan sistem pendukung keputusan menggunakan UML.

\section{A. Analisis data dengan servqual}

Data yang dianalisis dalam penelitian ini dikumpulkan menggunakan alat pengumpulan data berupa kuesioner yang terdiri dari 32 atribut pernyataan (Sunarto, 2011) yang dibagikan kepada pasien rumah sakit sebagai responden dengan teknik yang digunakan yaitu non probability sampling jenis purpose random sampling. Pengumpulan data dilaksanakan pada bulan Maret 2020 di Rumah Sakit Grandmed Lubuk Pakam dengan sample sebanyak 98 responden dengan total populasi 129 orang pasien rawat inap sebulan sebelum pengukuran ini dilakukan. Pengolahan data menggunakan perangkat lunak pengolah angka (spreadsheet).

TABEL I

ANALISIS SERVQUAL

\begin{tabular}{|c|c|c|c|}
\hline No. & Atribut & Skor Gap & Keputusan \\
\hline \multicolumn{4}{|c|}{ Bukti Fisik } \\
\hline 1 & BF01 & $-0,29$ & Perbaikan \\
\hline 2 & BF02 & 0,67 & Pertahankan \\
\hline 3 & BF03 & 0,68 & Pertahankan \\
\hline 4 & BF04 & 0,23 & Pertahankan \\
\hline 5 & BF05 & 0,12 & Pertahankan \\
\hline 6 & BF06 & 0,35 & Pertahankan \\
\hline 7 & BF07 & $-0,32$ & Perbaikan \\
\hline 8 & BF08 & $-0,21$ & Perbaikan \\
\hline
\end{tabular}

\begin{tabular}{|c|c|c|c|}
\hline \multicolumn{4}{|c|}{ Kehandalan } \\
\hline 9 & KH01 & 0,18 & Pertahankan \\
\hline 10 & KH02 & 0,14 & Pertahankan \\
\hline 11 & KH03 & 0,29 & Pertahankan \\
\hline 12 & KH04 & $-0,35$ & Perbaikan \\
\hline 13 & KH05 & $-0,21$ & Perbaikan \\
\hline 14 & KH06 & 0,34 & Pertahankan \\
\hline 15 & KH07 & 0,17 & Pertahankan \\
\hline
\end{tabular}

\section{Daya Tanggap}

\begin{tabular}{|l|l|c|l|}
\hline 16 & DY01 & 0,05 & Pertahankan \\
\hline 17 & DY02 & 0,10 & Pertahankan \\
\hline 18 & DY03 & $-0,24$ & Perbaikan \\
\hline 19 & DY04 & $-0,27$ & Perbaikan \\
\hline 20 & DY05 & 0,27 & Pertahankan \\
\hline 21 & DY06 & $-0,40$ & Perbaikan \\
\hline
\end{tabular}

\begin{tabular}{|l|l|c|l|}
\hline \multicolumn{2}{|c|}{ Jaminan } & 0,27 & Pertahankan \\
\hline 22 & JM01 & 0,01 & Pertahankan \\
\hline 23 & JM02 & $-0,16$ & Perbaikan \\
\hline 24 & JM03 & 0,30 & Pertahankan \\
\hline 25 & JM04 & 0,18 & Pertahankan \\
\hline 26 & JM05 & 0,71 & Pertahankan \\
\hline 27 & JM06 & 0,16 & Pertahankan \\
\hline \multicolumn{2}{|c|}{ Empati } & $-0,21$ & Perbaikan \\
\hline 28 & EM01 & 0,20 & Pertahankan \\
\hline 29 & EM02 & 0,18 & Pertahankan \\
\hline 30 & EM03 & 0,24 & Pertahankan \\
\hline 31 & EM04 & &
\end{tabular}

Dari tabel I dapat diketahui bahwa terdapat 10 atribut yang harus dilakukan perbaikan kualitas pelayanannya dan yang lainnya agar tetap dipertahankan.

TABEL II

PRIORITAS PERBAIKAN PELAYANAN

\begin{tabular}{|c|c|c|}
\hline Atribut & Skor Gap & Prioritas \\
\hline DT05 & $-0,40$ & 1 \\
\hline KH04 & $-0,35$ & 2 \\
\hline BF07 & $-0,32$ & 3 \\
\hline BF01 & $-0,29$ & 4 \\
\hline
\end{tabular}




\begin{tabular}{|c|c|c|}
\hline DT03 & $-0,27$ & 5 \\
\hline DT02 & $-0,24$ & 6 \\
\hline EM02 & $-0,21$ & 7 \\
\hline KH05 & $-0,21$ & 8 \\
\hline BF08 & $-0,21$ & 9 \\
\hline JM03 & $-0,16$ & 10 \\
\hline JM02 & 0,01 & 11 \\
\hline KH08 & 0,05 & 12 \\
\hline DT01 & 0,10 & 13 \\
\hline BF05 & 0,12 & 14 \\
\hline KH02 & 0,14 & 15 \\
\hline EM01 & 0,16 & 16 \\
\hline KH07 & 0,17 & 17 \\
\hline EM04 & 0,18 & 18 \\
\hline JM05 & 0,18 & 19 \\
\hline KH01 & 0,18 & 20 \\
\hline EM03 & 0,20 & 21 \\
\hline BF04 & 0,23 & 22 \\
\hline EM05 & 0,24 & 23 \\
\hline JM01 & 0,27 & 24 \\
\hline DT04 & 0,27 & 25 \\
\hline KH03 & 0,29 & 26 \\
\hline JM04 & 0,30 & 27 \\
\hline KH06 & 0,34 & 28 \\
\hline BF06 & 0,35 & 32 \\
\hline BF02 & 0,67 & 31 \\
\hline BF03 & 0,68 & \\
\hline JM06 & 0,71 & 32 \\
\hline & & \\
\hline
\end{tabular}

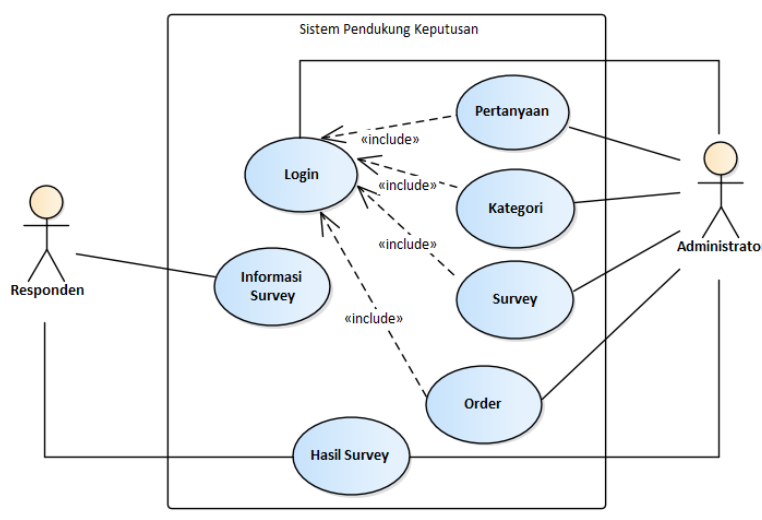

Gbr.1 Use Case Diagram

2) Class Diagram

Untuk rancangan database yang digunakan terdiri dari 7 tabel, yang terdiri dari :

- tbl_question, menampung data-data pertanyaan secara umum.

- tbl_category, menampung data-data dari kategori (dalam hal ini berisi dimensidimensi dari servqual).

- tbl_survey, menampung informasi dari survey-survey yang dilakukan.

- tbl_order, menampung data survey yang telah digabungkan dengan data pertanyaan dan diurutkan berdasarkan kategori.

Untuk perbaikan kualitas pelayanan berdasarkan prioritas dari atribut-atribut agar dilakukan secara berurutan seperti terlihat pada table II dan lebih di prioritaskan lagi pada atribut yang skor gap-nya yang bernilai negatif.

\section{B. Perancangan Sistem Pendukung Keputusan}

Berdasarkan observasi lapangan dan wawancara, untuk mempermudah, mempercepat dan mendapatkan hasil pengelohan data yang terjamin keakuratan dari pengukuran tingkat kepuasan pasien akan pelayanan maka penulis membangun sistem pendukung keputusan dengan rancangan menggunakan UML, sebagai berikut:

1) Use Case Diagram

Terdapat 2 aktor yang dapat mengakses sistem dengan peran yang berbeda-beda. Responden hanya dapat melihat informasi survey dan mengisinya serta melihat hasil dari survey. Administrator memiliki peran yang lebih besar seperti memasukkan daftar pernyataan, memasukkan kategori dari pertanyaan, memasukkan informasi survey dan mengurutkan seluruh pertanyaan dan kategori kedalam survey. Seluruh kegiatan dari administrator harus dilakukan terlebih dari dengan login ke sistem.
- tbl_responden, menampung data responden yang mengisi survey.

- tbl_respon, menampung data-data jawaban dari responden setelah mengisi survey.

- tbl_user, menampung data dari akun administrator

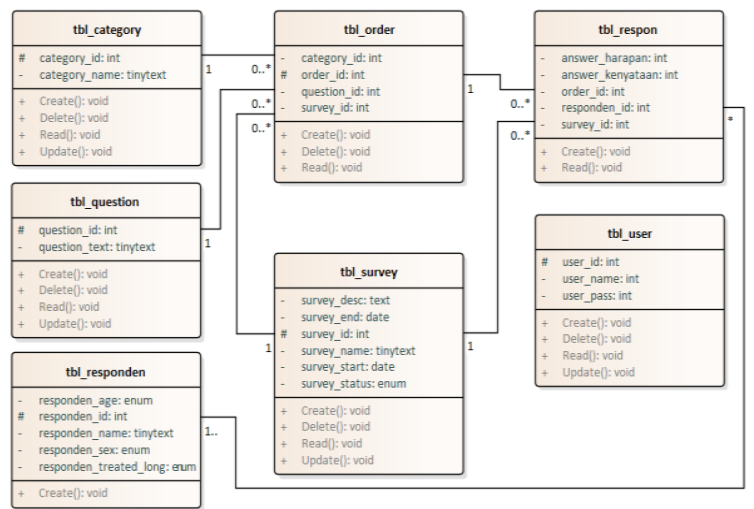

Gbr.2 Class Diagram

3) Activity Diagram

Use Case-Use Case dalam Use Case Diagram dibuat dalam bentuk yang lebih detail akan aktifitas-aktifitas dari proses yang akan berjalan dalam sistem. 
Page | 14

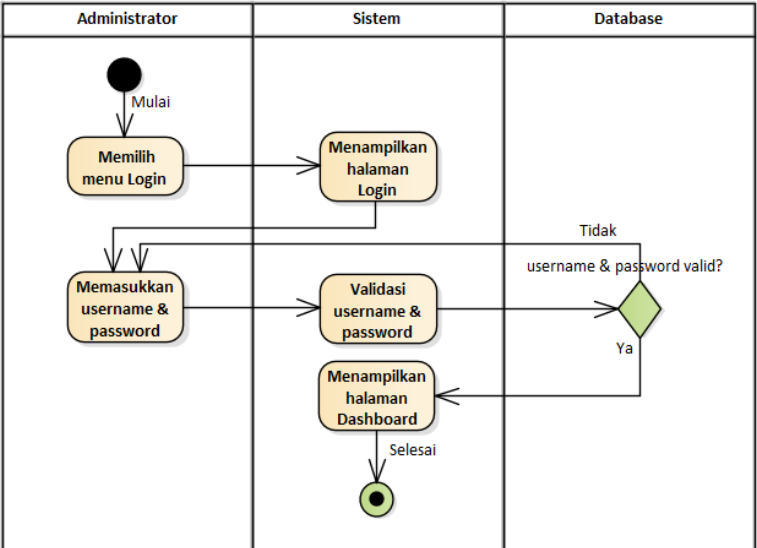

Gbr.3 Activity Diagram Login

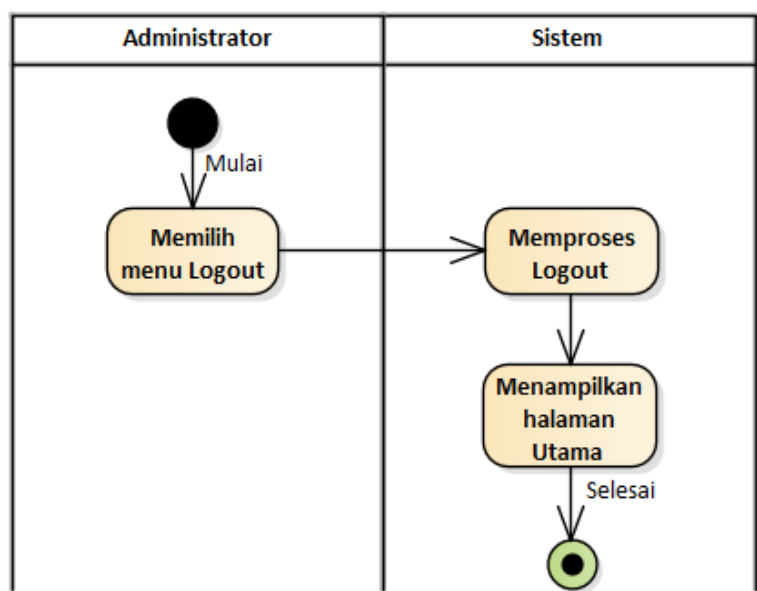

Gbr.4 Activity Diagram Logout

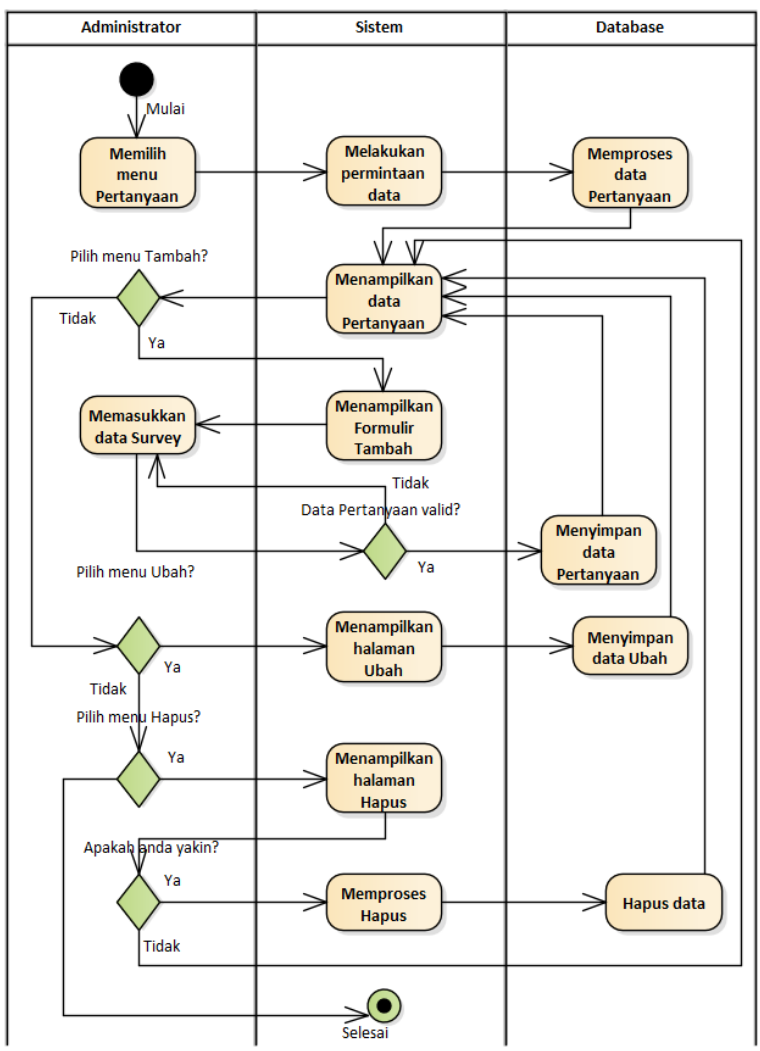

Gbr.5 Activity Diagram Pertanyaan

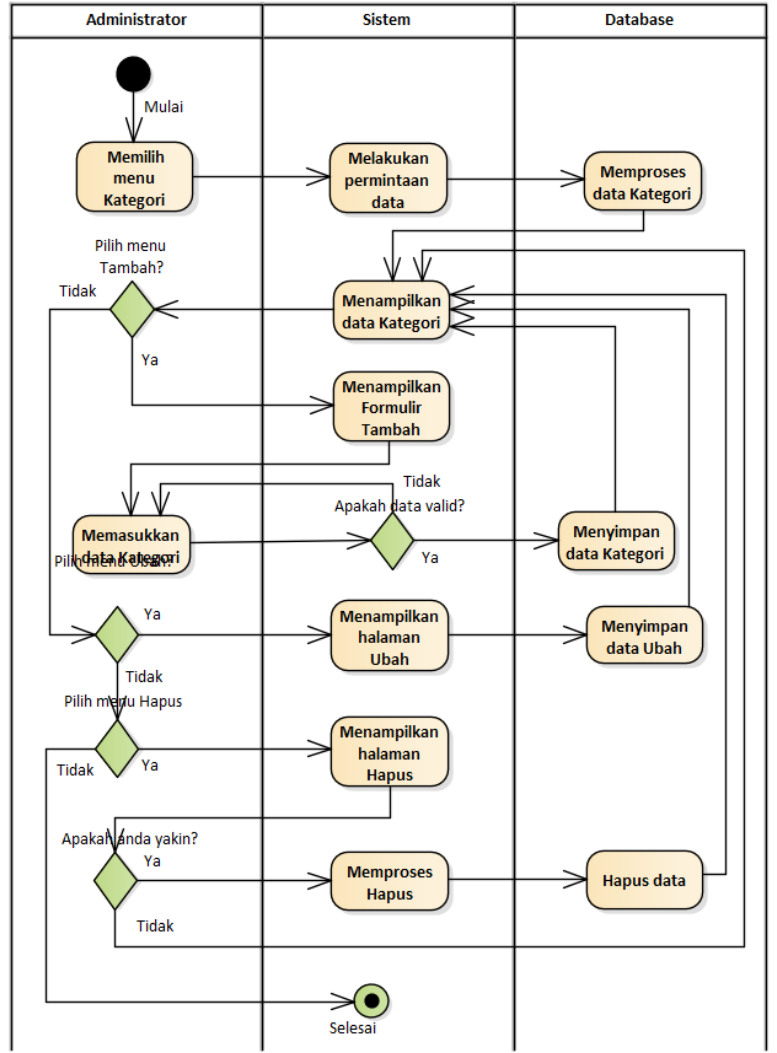

Gbr.6 Activity Diagram Kategori

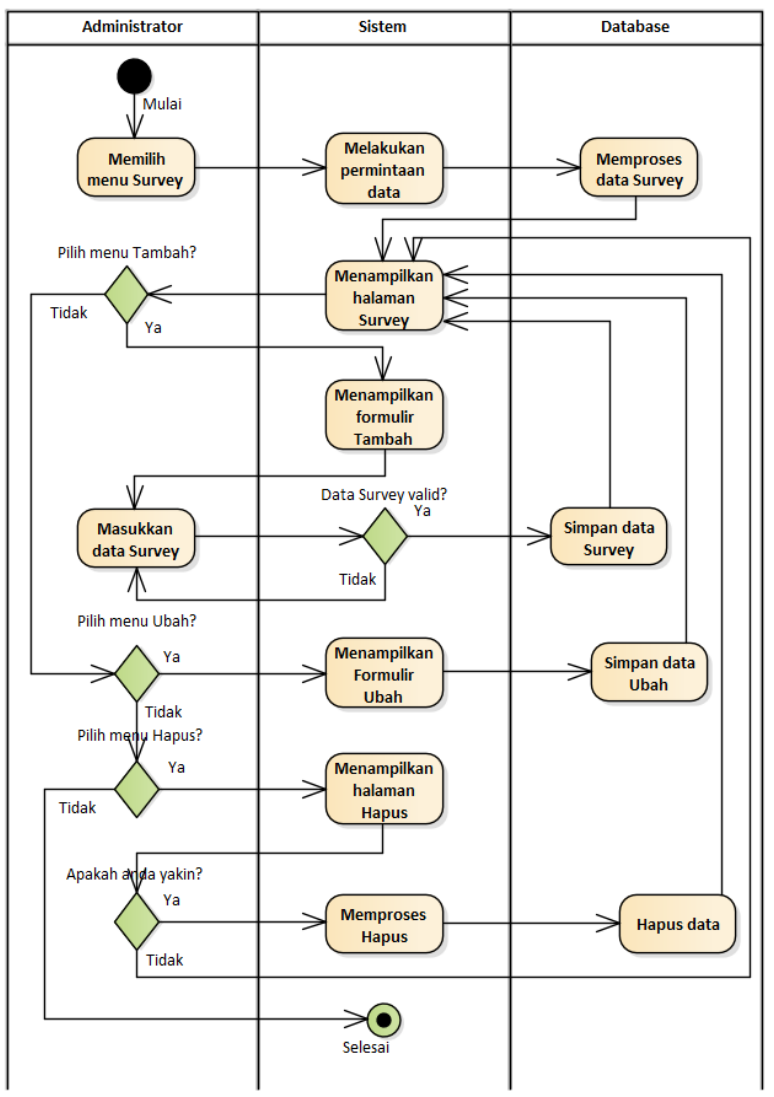

Gbr.7 Activity Diagram Survey 
Page | 15

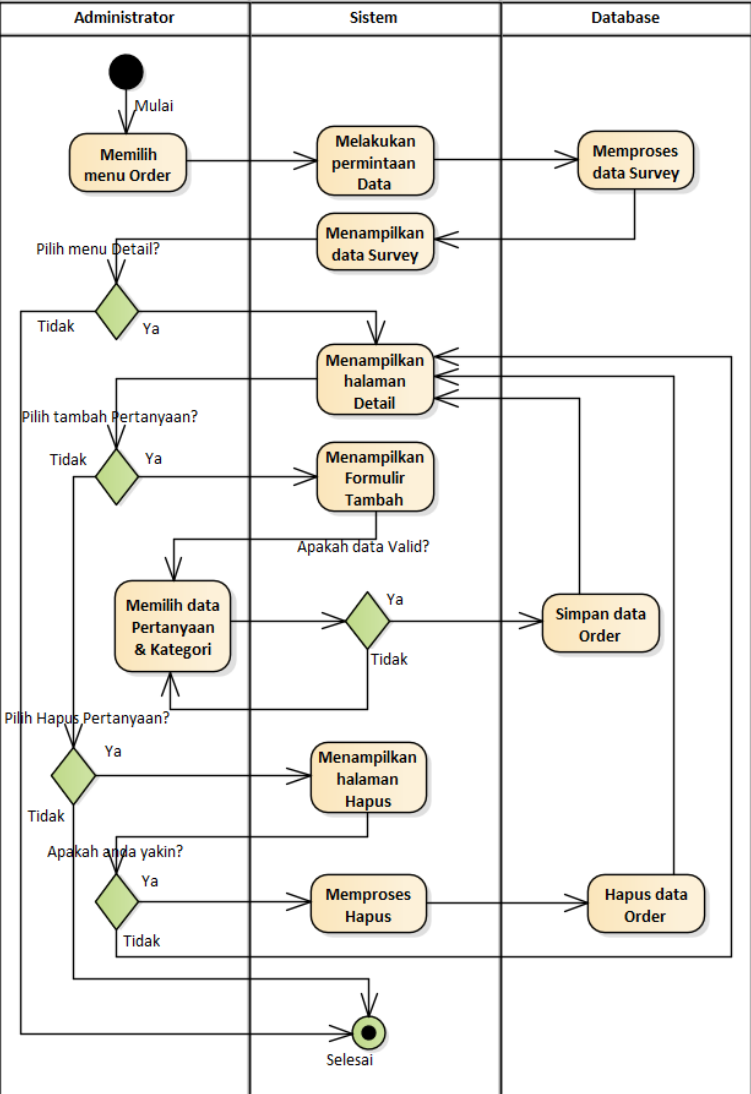

Gbr.8 Activity Diagram Order

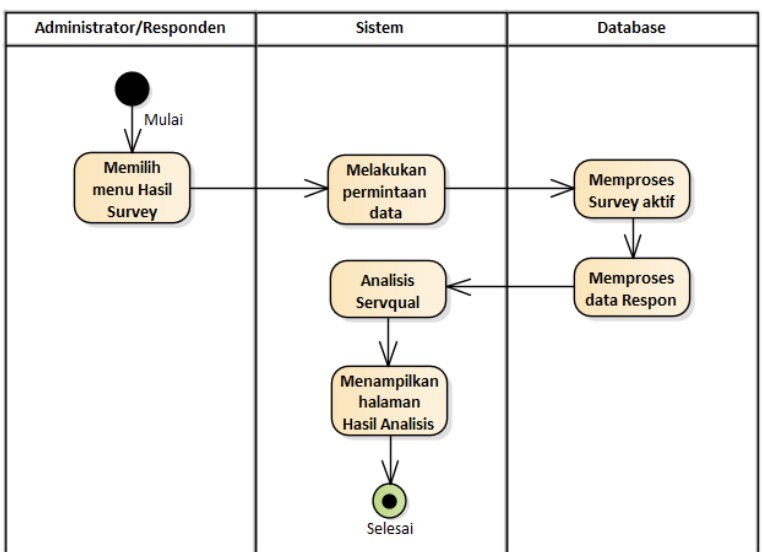

Gbr.9 Activity Diagram Hasil Survey

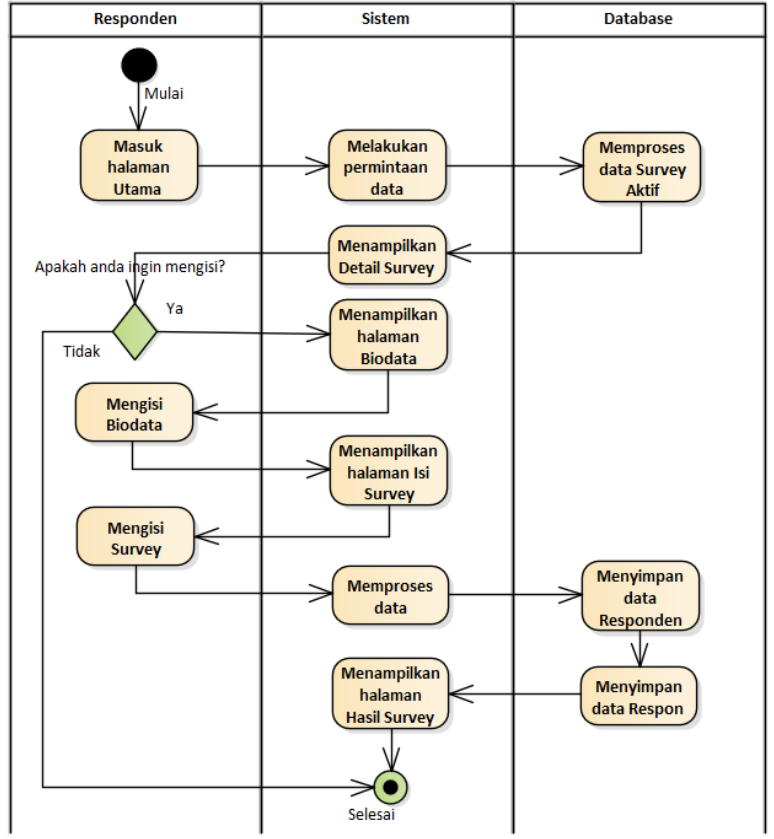

Gbr.10 Activity Diagram Informasi Survey

4) Sequence Diagram

Untuk memudahkan dalam pengembangan sistemnya, perilaku yang dilakukan oleh aktor beserta objek-objek dari sistem dibuat dalam bentuk yang berurutan dan berdasarkan rangkaian urutan penggunaan sistem.

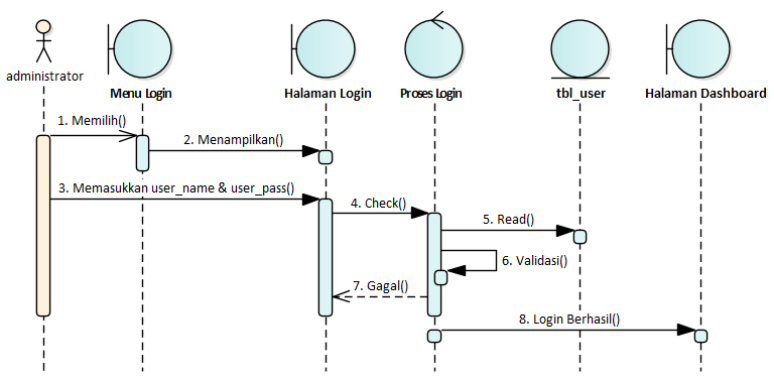

Gambar Sequence Diagram Login

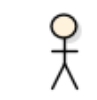

administrator
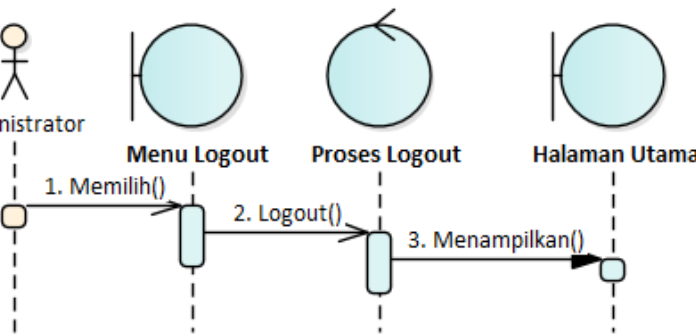

Gbr.11 Sequence Diagram Logout 


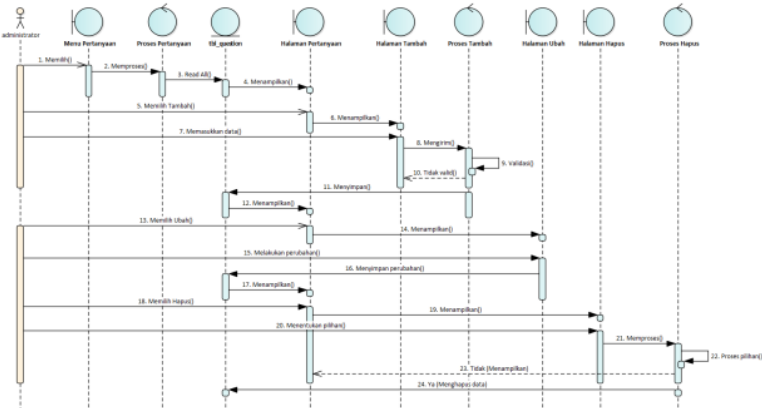

Gbr.12 Sequence Diagram Pertanyaan

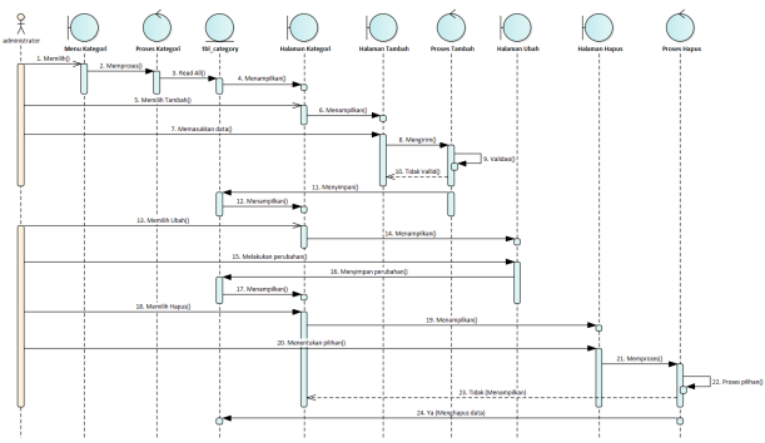

Gbr.13 Sequence Diagram Kategori

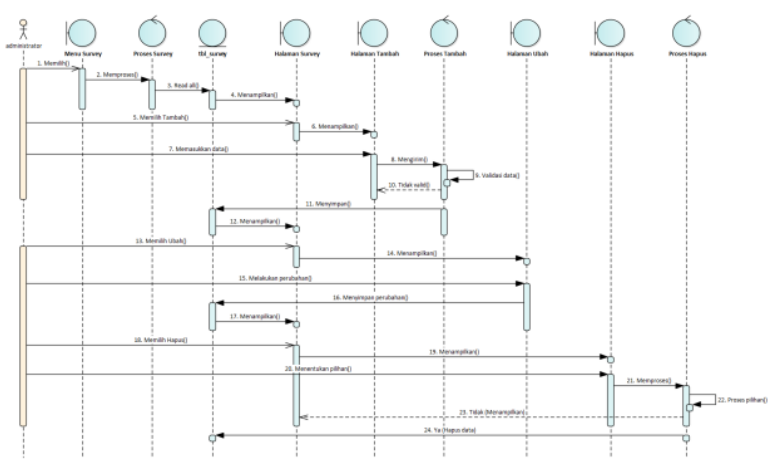

Gbr.14 Sequence Diagram Survey

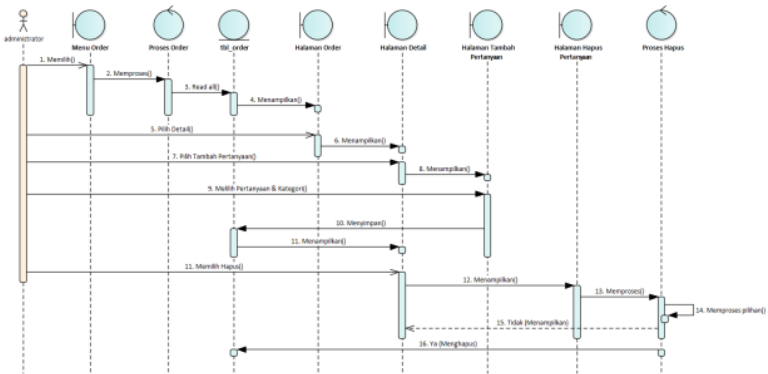

Gbr.15 Sequence Diagram Order

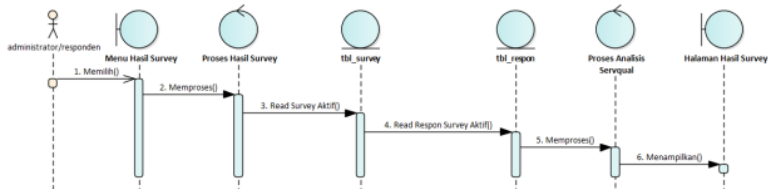

Gbr.16 Sequence Diagram Hasil Survey

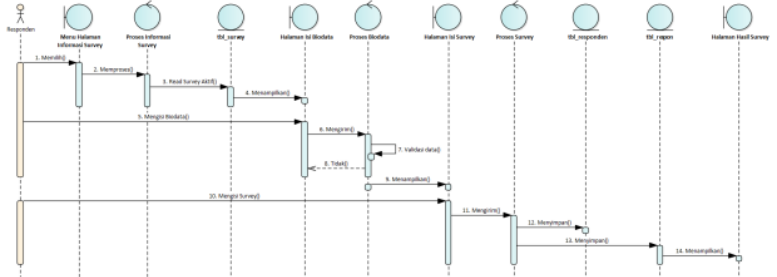

Gbr.17 Sequence Diagram Informasi Survey

5) Deployment Diagram

Dari gambar Deployment Diagram dapat dijelaskan agar sistem dapat berjalan dengan baik maka infrastruktur fisik juga harus terpenuhi berupa perangkat keras untuk server yang menyediakan layanan Web Server yang terbundel dengan PHP dan Database Management System (DBMS) MySQL Server. Dan Perangkat keras untuk client yang didalamnya telah ada Web Browser.

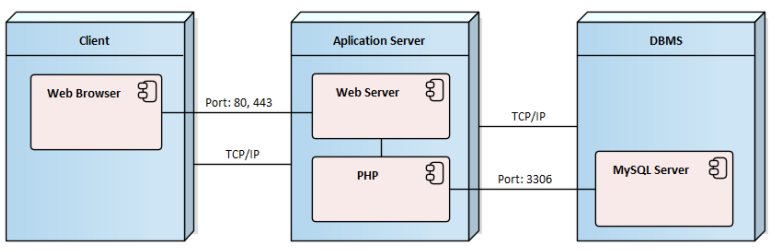

Gbr.18 Deployment Diagram

\section{HASIL DAN PEMBAHASAN}

Dalam bab ini akan dijelaskan hasil pengujian dari seluruh halaman-halaman dari sistem pendukung keputusan yang dikembangkan dan dibahas halamanhalaman yang sangat penting dalam pengumpulan data, pengolahan dan analisis data.

\section{a. Hasil Pengujian}

Sistem pendukung keputusan yang telah dikembangkan sesuai dengan rancangan sistem kemudian dilakukan pengujian. Hasil pengujian sistem dapat dilihat pada tabel III untuk pengujian halaman responden dan tabel IV untuk pengujian halaman administrator.

TABEL III

HASIL PENGUJIAN HALAMAN RESPONDEN

\begin{tabular}{|l|l|c|}
\hline \multicolumn{1}{|c|}{ Aktifitas } & Hasil yang diharapkan & Keterangan \\
\hline $\begin{array}{l}\text { Responden } \\
\text { mengakses }\end{array}$ & $\begin{array}{l}\text { Menampilkan halaman } \\
\text { utama sistem pendukung } \\
\text { keputusan yang diawali } \\
\text { deskripsi akan survey dan } \\
\text { Form Biodata }\end{array}$ & Berhasil \\
\hline $\begin{array}{l}\text { Responden } \\
\text { mengisi } \\
\text { Biodata }\end{array}$ & $\begin{array}{l}\text { Seluruh inputan yang } \\
\text { dimasukkan oleh responden } \\
\text { divalidasi sesuai dengan } \\
\text { ketentuan }\end{array}$ & Berhasil \\
\hline $\begin{array}{l}\text { Klik } \\
\text { "Next" }\end{array}$ & $\begin{array}{l}\text { Informasi Biodata akan } \\
\text { disimpan dalam session dan } \\
\text { menampilkan halaman }\end{array}$ & Berhasil \\
Kuesioner
\end{tabular}




\begin{tabular}{|l|l|l|c|}
\hline $\begin{array}{l}\text { Responden } \\
\text { mengisi } \\
\text { Kuesioner }\end{array}$ & $\begin{array}{l}\text { Pilihan jawaban dari } \\
\text { atribut-atribut kuesioner } \\
\text { tidak boleh kosong }\end{array}$ & Berhasil \\
\cline { 2 - 4 } $\begin{array}{l}\text { Klik } \\
\text { "Next" }\end{array}$ & $\begin{array}{l}\text { Informasi Biodata dan } \\
\text { Kuesioner disimpan ke } \\
\text { database, menampilkan } \\
\text { halaman hasil }\end{array}$ & Berhasil \\
\cline { 2 - 5 } & $\begin{array}{l}\text { Hasil } \\
\text { Survey }\end{array}$ & $\begin{array}{l}\text { Halaman hasil survey } \\
\text { ditampilkan yang berisi } \\
\text { hasil pengolahan data dan } \\
\text { analisis servqual }\end{array}$ & Berhasil \\
\hline
\end{tabular}

TABEL IV

HASIL PENGUJIAN HALAMAN ADMINISTRATOR

\begin{tabular}{|c|c|c|}
\hline Aktifitas & Hasil yang diharapkan & Keterangan \\
\hline $\begin{array}{l}\text { Administrator } \\
\text { mengakses } \\
\text { URL }\end{array}$ & $\begin{array}{l}\text { Menampilkan halaman } \\
\text { utama sistem pendukung } \\
\text { keputusan }\end{array}$ & Berhasil \\
\hline $\begin{array}{l}\text { Klik menu } \\
\text { "Login" }\end{array}$ & $\begin{array}{l}\text { Menampilkan halaman } \\
\text { Login Administrator }\end{array}$ & Berhasil \\
\hline $\begin{array}{l}\text { Masukkan } \\
\text { Username } \\
\text { dan Password }\end{array}$ & $\begin{array}{l}\text { Proses validasi akun } \\
\text { administrator ke dalam } \\
\text { database, bila valid akan } \\
\text { menuju halaman } \\
\text { Dashboard yang } \\
\text { menampilkan menu } \\
\text { utama dan pesan selamat } \\
\text { datang }\end{array}$ & Berhasil \\
\hline $\begin{array}{l}\text { Klik menu } \\
\text { "Pertanyaan" }\end{array}$ & $\begin{array}{l}\text { Menampilkan halaman } \\
\text { yang berisi daftar-daftar } \\
\text { pertanyaan }\end{array}$ & Berhasil \\
\hline $\begin{array}{l}\text { Klik menu } \\
\text { "Pertanyaan > } \\
\text { Tambah" }\end{array}$ & $\begin{array}{l}\text { Menampilkan Form } \\
\text { Tambah Pertanyaan, } \\
\text { validasi hasil inputan } \\
\text { dan simpan ke dalam } \\
\text { database }\end{array}$ & Berhasil \\
\hline $\begin{array}{l}\text { Klik menu } \\
\text { "Pertanyaan > } \\
\text { Ubah" }\end{array}$ & $\begin{array}{l}\text { Menampilkan Form } \\
\text { Ubah Pertanyaan sesuai } \\
\text { dengan data yang } \\
\text { dipilih, validasi hasil } \\
\text { inputan dan update ke } \\
\text { dalam database }\end{array}$ & Berhasil \\
\hline $\begin{array}{l}\text { Klik menu } \\
\text { "Pertanyaan > } \\
\text { Hapus" }\end{array}$ & $\begin{array}{l}\text { Menampilkan Dialog } \\
\text { Hapus Pertanyaan sesuai } \\
\text { dengan pertanyaan yang } \\
\text { dipilih, Bila sudah yakin } \\
\text { klik "OK" dan hapus } \\
\text { dari database }\end{array}$ & Berhasil \\
\hline $\begin{array}{l}\text { Klik menu } \\
\text { "Kategori" }\end{array}$ & $\begin{array}{l}\text { Menampilkan halaman } \\
\text { yang berisi daftar-daftar } \\
\text { kategori pertanyaan }\end{array}$ & Berhasil \\
\hline $\begin{array}{l}\text { Klik menu } \\
\text { "Kategori > } \\
\text { Tambah" }\end{array}$ & $\begin{array}{l}\text { Menampilkan Form } \\
\text { Tambah Kategori, } \\
\text { validasi hasil inputan } \\
\text { dan simpan ke dalam } \\
\text { database }\end{array}$ & Berhasil \\
\hline $\begin{array}{l}\text { Klik menu } \\
\text { "Kategori > } \\
\text { Ubah" }\end{array}$ & $\begin{array}{l}\text { Menampilkan Form } \\
\text { Ubah Kategori sesuai } \\
\text { dengan data yang } \\
\text { dipilih, validasi hasil } \\
\text { inputan dan update ke } \\
\text { dalam database }\end{array}$ & Berhasil \\
\hline
\end{tabular}

\begin{tabular}{|c|c|c|}
\hline $\begin{array}{l}\text { Klik menu } \\
\text { "Kategori > } \\
\text { Hapus" }\end{array}$ & $\begin{array}{l}\text { Menampilkan Dialog } \\
\text { Hapus Pertanyaan sesuai } \\
\text { dengan data yang } \\
\text { dipilih, Bila sudah yakin } \\
\text { klik "OK" dan hapus } \\
\text { dari database }\end{array}$ & Berhasil \\
\hline $\begin{array}{l}\text { Klik menu } \\
\text { "Survey" }\end{array}$ & $\begin{array}{l}\text { Menampilkan halaman } \\
\text { yang berisi daftar-daftar } \\
\text { Survey }\end{array}$ & Berhasil \\
\hline $\begin{array}{l}\text { Klik menu } \\
\text { "Survey > } \\
\text { Tambah" }\end{array}$ & $\begin{array}{l}\text { Menampilkan Form } \\
\text { Tambah Survey, validasi } \\
\text { hasil inputan dan simpan } \\
\text { ke dalam database }\end{array}$ & Berhasil \\
\hline $\begin{array}{l}\text { Klik menu } \\
\text { "Survey > } \\
\text { Ubah" }\end{array}$ & $\begin{array}{l}\text { Menampilkan Form } \\
\text { Ubah Survey sesuai } \\
\text { dengan data yang } \\
\text { dipilih, validasi hasil } \\
\text { inputan dan update ke } \\
\text { dalam database }\end{array}$ & Berhasil \\
\hline $\begin{array}{l}\text { Klik menu } \\
\text { "Survey > } \\
\text { Hapus" }\end{array}$ & $\begin{array}{l}\text { Menampilkan Dialog } \\
\text { Hapus Survey sesuai } \\
\text { dengan data yang } \\
\text { dipilih, Bila sudah yakin } \\
\text { klik "OK" dan hapus } \\
\text { dari database } \\
\end{array}$ & Berhasil \\
\hline $\begin{array}{l}\text { Klik menu } \\
\text { "Order" }\end{array}$ & $\begin{array}{l}\text { Menampilkan halaman } \\
\text { yang berisi daftar-daftar } \\
\text { Order }\end{array}$ & Berhasil \\
\hline $\begin{array}{l}\text { Klik menu } \\
\text { "Order > } \\
\text { Detail" }\end{array}$ & $\begin{array}{l}\text { Menampilkan Detail dari } \\
\text { salah satu Survey }\end{array}$ & Berhasil \\
\hline $\begin{array}{l}\text { Klik menu } \\
\text { "Order > } \\
\text { Detail > } \\
\text { Populate" }\end{array}$ & $\begin{array}{l}\text { Menampilkan Form } \\
\text { untuk menambahkan } \\
\text { pertanyaan dan } \\
\text { kategorinya ke dalam } \\
\text { Survey yang dipilih } \\
\end{array}$ & Berhasil \\
\hline $\begin{array}{l}\text { Klik menu } \\
\text { "Hasil" }\end{array}$ & $\begin{array}{l}\text { Menampilkan halaman } \\
\text { yang berisi hasil analisis } \\
\text { dari survey yang aktif }\end{array}$ & Berhasil \\
\hline $\begin{array}{l}\text { Klik menu } \\
\text { "Logout" }\end{array}$ & $\begin{array}{l}\text { Menghapus session } \\
\text { login dan kembali ke } \\
\text { halaman utama }\end{array}$ & Berhasil \\
\hline
\end{tabular}

\section{b. Pembahasan}

Data-data hasil masukan dari responden maupun administrator dibahas sesuai dengan hasil dari pengembangan dari sistem pendukung keputusan yang dikembangkan.

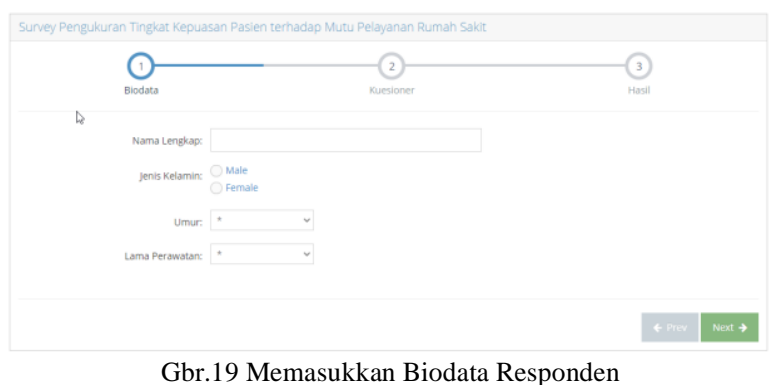

Pada halaman formulir Biodata yang tampak pada gambar diatas berisi inputan berupa nama, jenis kelamin, umur dan lama perawatan dari responden. 
Data yang dihasilkan dari halaman ini akan diolah untuk mendapatkan informasi karakteristik dari seluruh responden yang mengikuti survey.

Page | 18

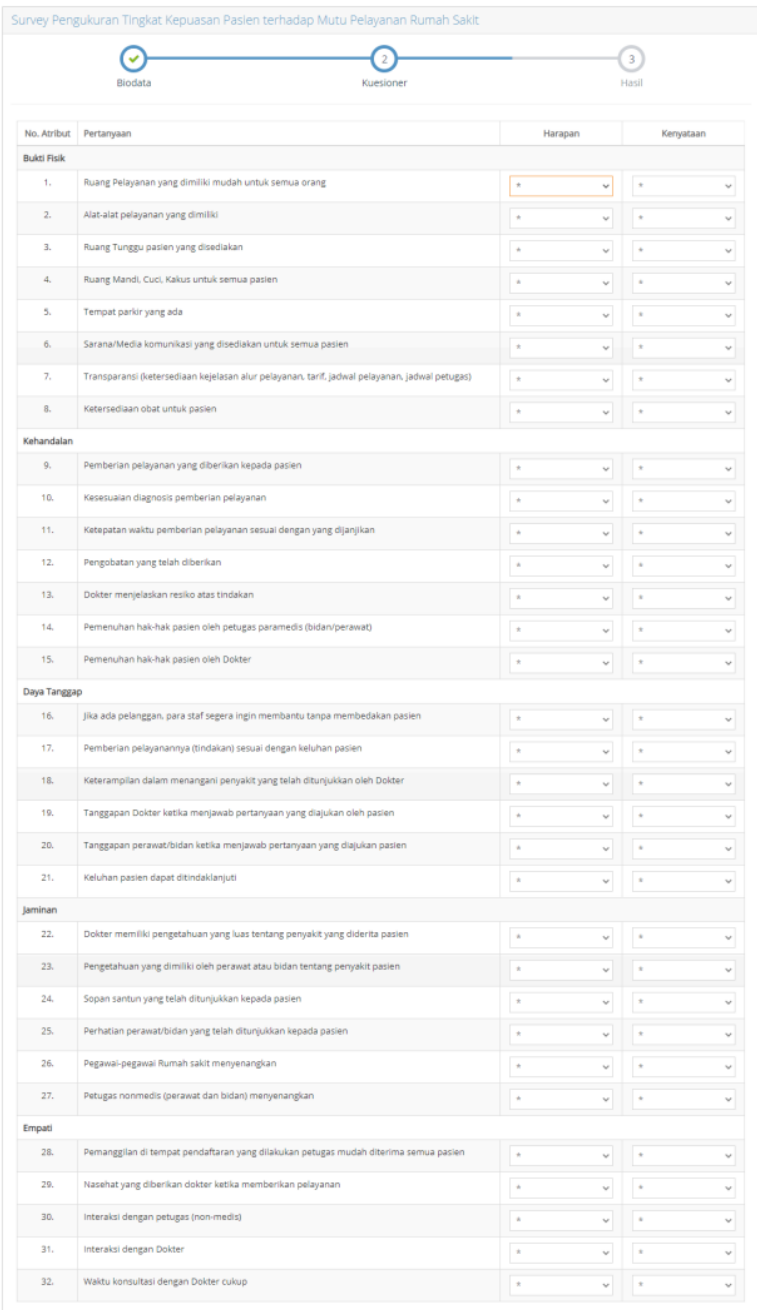

Gbr.20 Pengisian Kuesioner

Halaman kuesioner akan menampilkan daftar atribut-atribut yang harus diisi oleh responden. Jawaban dari setiap atribut terdiri dari Harapan dan Kenyataan yang menggunakan skala likert. Atributatribut dikategorikan berdasarkan dimensi-dimensi dari Servqual seperti tampak pada gambar diatas.

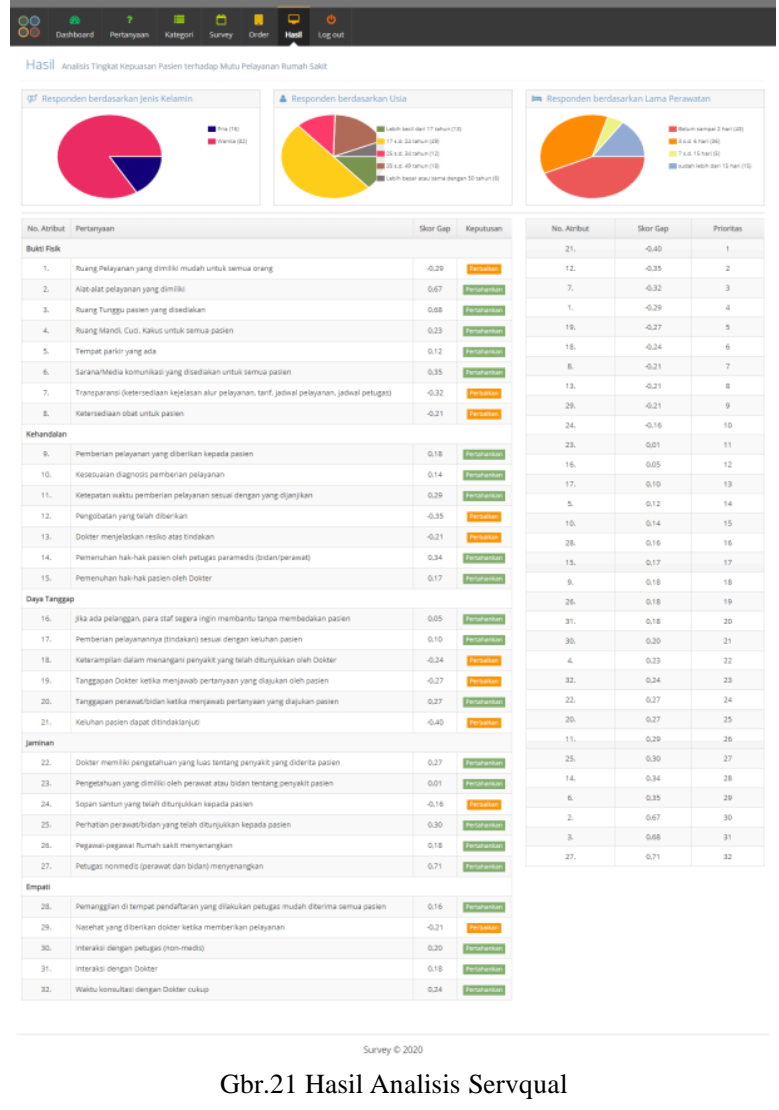

Halaman Hasil Analisis Servqual merupakan hasil akhir dari pelaksanaan dari pengukuran tingkat kepuasan. Hasil pengolahan data Biodata dan Kuesioner dapat digunakan sebagai data pendukung untuk pengambilan keputusan dalam meningkatkan mutu pelayanan kepada pasien.

\section{PENUTUP}

Berdasarkan hasil analisis, perancangan dan sistem yang telah dibangun maka dapat diambil kesimpulan:

1. Hasil analisis data menggunakan metode servqual dapat memberikan informasi yang akurat dan menjadi data pendukung dalam pengambilan keputusan untuk meningkatkan kualitas pelayanan kepada pasien rumah sakit.

2. Sistem pendukung keputusan yang telah dibangun berdasarkan rancangan menggunakan UML dapat menghasilkan hasil analisis yang akurat, cepat dan tepat dan sesuai dengan perhitungan dengan menggunakan perangkat lunak pengolah angka (spear sheet).

\section{UCAPAN TERIMA KASIH}

Puji dan syukur kehadirat Tuhan Yang Maha Kuasa atas berkat dan rahmat serta kesempatan yang diberikan kepada kami untuk menyelesaikan penelitian ini. Ucapan terima kasih peneliti juga kepada Direktorat Jenderal Pendidkan Tinggi Kementerian Pendidikan dan Kebudayaan yang memberikan seluruh dana penelitian ini melalui hibah penelitian skema Penelitian Dosen Pemula (PDP) 2019 pelaksanaan 
tahun 2020. Tidak luput juga kami ucapan terima kasih kepada seluruh jajaran rumah sakit Grandmed yang memberikan tempat dan waktu kepada kami dalam melaksanakan penelitian ini hingga selesai. Serta ucapan terima kasih kepada seluruh pihak yang Page | 19 membantu penelitian ini hingga selesai.

\section{REFERENSI}

[1] Rohayani, H. 2013. Analisis Sistem Pendukung Keputusan dalam Memilih Program Studi menggunakan Metode Logika Fuzzy. Jurnal Sistem Informasi, Vol. 5, No. 1, April 2013, hal. 530-539

[2] Irawan, B., Kurnia, R., Sitanggang, E., \& Achmady, S. (2020). Analisis Tingkat Kepuasan Pasien Terhadap Mutu Pelayanan Rumah Sakit Berdasarkan Metode Service Quality (servqual) Jurnal Keperawatan dan Fisioterapi (JKF), 3(1), 58-64. https://doi.org/10.35451/jkf.v3i1.522.

[3] Sitanggang, E. D, Tulus and Nasution, B. B. 2018. Analysis of Satisfaction Level with Servqual method using Artificial Neural Networks. The $3^{\text {rd }}$ International Conference on Computing and Applied Informatics (ICCAI). Septermber 2018.

[4] Putra, D. W. T. dan Andriani R. 2019. Unified Modelling Language (UML) dalam Perancangan Sistem Informasi Permohonan Pembayaran Restribusi SPPD. Jurnal TEKNOIF, Vol. 7, No. 1, April 2019, hal. 32-39.

[5] Sukmawati R. dan Priyadi Y. 2019. Perancangan Proses Bisnis Menggunakan UML Berdasarkan Fit/Gap Analysis Pada Modul Inventory Odoo. Jurnal Ilmiah Penelitian dan Penerapan Teknolog, Vol. 3, No. 2, Agustus 2019, hal. 104 115.

[6] Ghiffary, M. N. E., Susanto, T. D. dan Herdiyanti, A. 2018 Analisis Komponen Desain Layout, Warna, dan Kontrol Pada Antarmuka Pengguna Aplikasi Mobile Berdasarkan Kemudahan Penggunaan (Studi Kasus: Aplikasi Olride) Jurnal Teknik ITS, Vol. 7, No. 1, 2018, hal. 143-148.

[7] Sunarto. 2011. Analisis Tingkat Kepuasan dan Harapan Pasien Terhadap Pelayanan Puskesmas dan Rumah Sakit Daerah di Propinsi DIY. Jurnal Kesehatan Masyarakat, Vol. 5, No. 1, Maret 2011, hal. 28-35. 